\title{
Seasonal and Spatial Distribution of N \& P Substances in the Hula Valley (Israel) Subterranean
}

\author{
M. Gophen*, M. Meron, V. Orlov-Levin, Y. Tsipris \\ Migal-The Upper Galilee Scientific Research Institute, Kiryat Shmona, Israel \\ Email: ${ }^{*}$ Gophen@Migal.org.il
}

Received 23 July 2014; revised 22 August 2014; accepted 22 September 2014

Copyright $@ 2014$ by authors and Scientific Research Publishing Inc.

This work is licensed under the Creative Commons Attribution International License (CC BY). http://creativecommons.org/licenses/by/4.0/

(c) (i) Open Access

\section{Abstract}

Until the late 1950s the Hula Valley, located between altitude of 170 masl in the northern part and 61 masl in the southern part, was covered by the old shallow Lake Hula (1.5 m mean depth; 1400 ha water surface); and 4500 ha of swamps partly or permanently were water covered. During 1950-1957 the old Lake Hula and the wetlands were drained and converted into agricultural usage. As a result of inappropriate agricultural management, a reclamation project (Hula Project, HP, 1990-1997) was implemented. A vertical plastic sheet ( $4.5 \mathrm{~m}$ deep) was placed along $2.8 \mathrm{~km}$ across the valley aimed at reduction of pollutants migration. This plastic barrier divided the valley into northern, organic, and southern mineral soil blocks. The HP was aimed at agricultural renovation together with prevention of water quality deterioration in the downstream Lake Kinneret. The chemical composition of the underground waters was monitored on a monthly basis in 14 drills and ground water table observation wells over the valley during 14 months. The Ground Water Table (GWT) in the northern part of the valley was shallower than in the south and seasonal fluctuation amplitudes were smaller in the north. Higher levels of TP, TDP, P-Ortho and particulate Phosphorus, TN and ammonium were documented in the southern underground waters. The level of nutrient concentrations in the south was probably enhanced by three factors: 1) accumulation by underground water migration; 2 ) eroded substances from the southern mineral soil; 3 ) intensive Evapo-Transpiration in the south. Due to the lower level of organic content in the south and in spite of possible underground accumulation no significant difference between southern and northern blocks was indicated for Nitrate $\left.\mathrm{NO}_{3}\right)$ concentrations. Not like nitrates, the reduced nitrogen form of ammonium concentration in the undergrounds was higher in the south. It was suggested that the nutrient concentrations (dissolved and suspended) in the Southern underground waters were higher than those in the North as a result of water migration, which took over the plastic barrier underneath and/or aside while moving from north to south was resulted by the hydraulic gradient. This gradient was partly due to the topographic slope and partly to the inten-

*Corresponding author. 
sive Evapo-Transpiration in this part of the valley, which also contributed to the decline of GWT. Keywords

Hula Valley, Undergrounds, Running Waters, Nutrients

\section{Introduction}

Settling in the Hula Valley by the Ghawarna tribes was initiated during the 4th decade of the 19th century and came to an end abruptly in 1948. The development of the Ghawarna settling was very slow during the 19th century and significantly accelerated during the 1 st half of the 20th century. British sources reported that in 1877 there were 520 Ghawarna residents settling in the Hula valley and that the number reached 12,400 in 1935 [1].

In 1941, 13,350 residents were documented and in 1948 the number was 31,740. Prior to 1830 there were no permanent settlements of Ghawarna in the Hula Valley. Residents from the region came down from surrounded mountains with their cattle herds for grazing and for agricultural cropping in summer time and stayed most of the summer months in those parts of the valley which were not inundated. This was the summer paradox of the Hula wetlands prior to the 20th century: the much drier was the winter, the more grass for cattle grazing and land for agriculture were available. The cultivated land was like a puzzle of plots, namely, "Mazraa" (or "Azeva"). If we went further back in time, Karmon [2] concluded that the Hula Valley was turned into a wilderness by the Mongolian from 1240 AD. Karmon [2] also suggested that the Malaria was introduced into the Hula Valley by the Crusaders and inundation of the Hula Valley was enhanced as a result of the construction of Benot Yaakov Bridge downstream by Bivers in 1260. Later on the Malaria became the major parameter which affected human activity in the Hula wetlands. The history of Jewish settlements in the upper Galilee and particularly in the Hula Valley and its vicinity started during the end of the 19th century and the beginning of the 20th century. Nevertheless the intensive Jewish settling in the Hula Valley region started during the 1940s of the previous century. Two years after the Israeli Independent war and the creation of the Jewish state (1948) drainage in the Old Lake Hula and the adjacent swampy area began and was completed in 1955. The lake-wetland area was converted into agriculture. Beneficial crops were produced but not without difficulties.

\subsection{Regional Hydrology [3]-[5]}

Three major rivers (Hatzbani, Banyas and Dan) flowed from the Hermon mountain region, located in the north part of the Kinneret drainage basin. These rivers joint into one river Jordan which before Hula drainage crossed the valley in two branch (tributaries) inflows into old Lake Hula. From Lake Hula at an altitude of about $61 \mathrm{~m}$ masl River Jordan flowed downstream into Lake Kinneret to an altitude of $209 \mathrm{~m}$ below sea level along about 15 $\mathrm{km}$. The Jordan River contributed about $63 \%$ of the Kinneret water budget and most of the total external nutrient inputs until the drainage. The Hula Valley $(62.00-70.00 \mathrm{~m}$ masl) was covered by the shallow Lake Hula $(1.5 \mathrm{~m}$ mean depth; $13 \mathrm{~km}^{2}$ water surface) and 4500 ha of swamps. The swampy area was completely water-covered in winter and partly covered in summer. Northern to the swamps there was an area (3200 ha) where water table levels were high in winter time, making agricultural development impossible. During summer periods when underground water levels declined, these 3200 ha were successfully cultivated.

\subsection{Post Drainage [3]}

As a result of the lake and wetland drainage more than 6500 ha of natural wetland areas were converted into agricultural development. Nevertheless, unique natural composition of fauna and flora of exceptional diversity was almost demolished. The newly created agricultural land-use contributed an income resource to the residents of the northern part of Israel. During 40 years it was successfully cultivated and agricultural products (mostly cotton, corn, Alfa and vegetables) were economically produced and nutrient flux into Lake Kinneret did not threaten its water quality. Nevertheless, as a result of inappropriate management, drainage canals were blocked. Irrigation methods were not suitable for optimal soil management and its fertility, and crop utilization and water tables declined.

Consequently, soil structure of upper layers $(0-0.5 \mathrm{~m})$ was oxidized and deteriorated, heavy dust storms be- 
came frequent, and soil surface subsided $(7-10 \mathrm{~cm} /$ year). Due to the decline of water table level and longer periods of uncultivated bare and dry soils, underground fires occurred quite often. Rodent population outbreaks caused severe damage to agricultural crops and stability of drainage canal banks. In the 1980's intensive cultivation of land was gradually abandoned. Therefore, the whole drainage area went through reclamation project, focusing on the 500 ha located in the middle part of the valley at the lowest altitude, referred as the Hula Project (HP) during 1990-1997. The project was aimed primarily at the reduction of nutrient fluxes from Hula soil while implementing modern irrigation methods to reintroduce economical land-use management and integration of ecotourism. The reclamation project [4] [5] included several operational elements, namely, an increase of soil moi- sture by elevating the ground water table (GWT), changing the irrigation method and renewing the drainage system in the entire valley, which created a new shallow Lake Agmon $(0.5 \mathrm{~m}$ average depth; 110 ha surface area) to be operated as a drainage basin for the valley and Eco-Touristic wetlands. A plastic sheet (4 mm thickness) was placed (Photo 1) vertically $(0-4.5 \mathrm{~m})$ along $2.8 \mathrm{~km}$, crossing the west-southern part of the valley, to separate ground water tables and to prevent underground migration of pollutants downstream to Lake Kinneret.

The aim of this paper was to give an insight into the interrelation between underground and surface running waters in the Hula Valley. It was crucial for the knowledge of comprehensive nutrient balance and its impact on pollutant flux regime from the valley downstream to Lake Kinneret as well as for understanding soil degradation process as basis for fertilization design of the cultivated crops.

\section{Material and Methods [3]}

Total Nitrogen and Total Phosphorus (among other elements) in running waters were measured routinely on a monthly basis in the northern (4 stations) and in the southern (4 stations) parts of the Hula Valley (Hula Project Annual Reports 1994-2008). Monthly measurements of underground surface water altitude were monitored in 32 drills (Hula Project Annual Reports 2002-2014) in the valley. During 2006-2009 the chemical composition of the underground waters was measured in monthly collected samples in the 14 drills by a peristaltic pump.

Running Water Sampling Stations (Figure 1):

Northern Region

1) Reconstructed Jordan.

2) Major Peat drainage Canal (Canal Z).

3) Lake Agmon outflow.

Southern Region

4) "Zero" Canal.

5) 404 Canal.

6) 312 Canal.

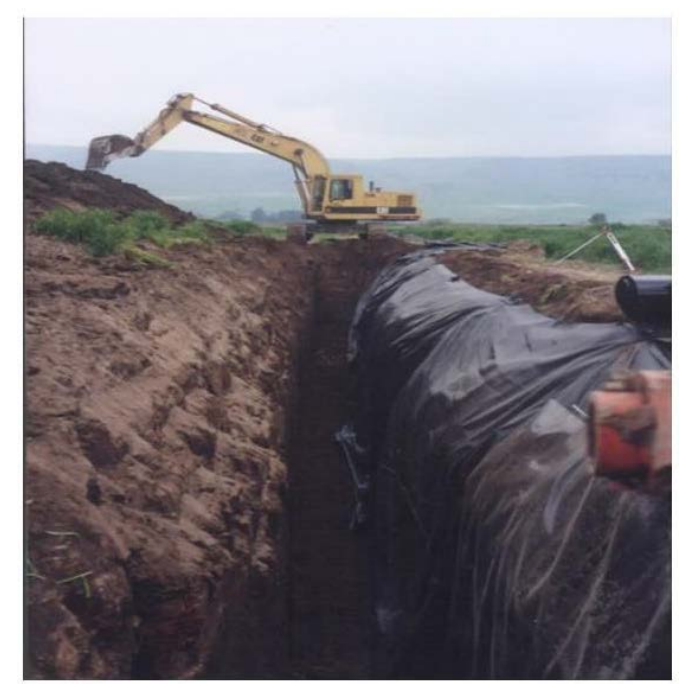

Photo 1. Placing of the plastic barrier (1994). 


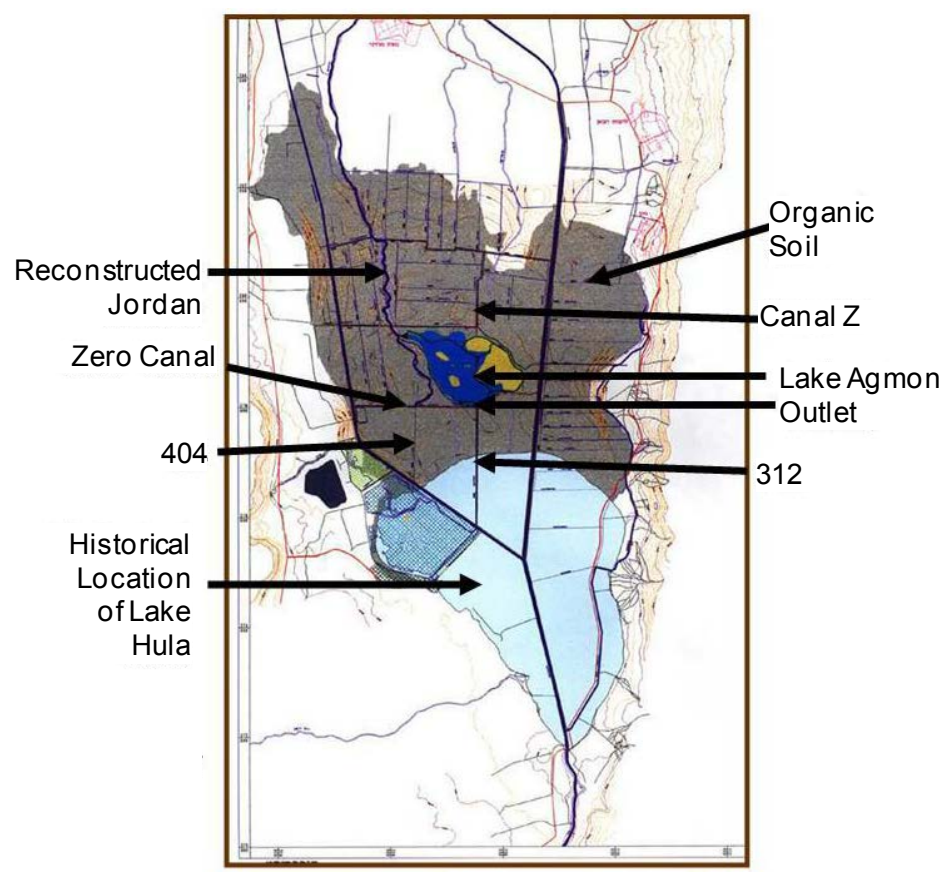

Figure 1. Schematic map chart of the Hula Valley with indication of running water sampling Stations.

The following parameters were analyzed and reported here: TP, TDP, Particulate-P, $\mathrm{P}-\mathrm{PO}_{4}, \mathrm{TN}, \mathrm{NH}_{4}, \mathrm{NO}_{3}$, and TDN. Other monitored chemical measurements which were not reported in this paper were: $\mathrm{pH}, \mathrm{DO}, \mathrm{SO}_{4}$, and Alkalinity. The chemical analyses were carried out in the Migal Chemical Analytical Laboratory.

\section{Results}

The fluctuations of monthly averages of TP and TN concentrations in the underground and running waters of the northern and southern stations and drills are shown in Figures 2-5 and Table 1 represent the annual averages (SD) of the Northern and Southern stations (running waters) and drills (underground waters). Comparative ANOVA Test $(p<0.05)$ was done between North $(\mathrm{N})$ and South $(\mathrm{S})$ water compositions of running waters (HP) and the undergrounds (Under). Results give the following indications:

Running waters: TP $(\mathrm{S}<\mathrm{N})$, significant $(\mathrm{p}=0.0002)$; TN $(\mathrm{S}<\mathrm{N})$, not significant $(\mathrm{p}=0.6347)$. Underground waters: TP $(S>N)$, significant $(p<0.0001)$; TN $(S>N)$, significant $(p<0.0001)$.

The annual means of other $\mathrm{N}$ and $\mathrm{P}$ forms in the northern and southern underground waters are given in Table 2 and Figures 3-4. It is likely that the concentrations of Total Dissolved Phosphorus (TDP) and P-Ortho (P-Po4) relative to total phosphorus TP are not strongly diversified temporally. On the other hand the ratio between nitrate and ammonium is high in winter-spring season and turnaround (low $\mathrm{NO}_{3}$ ) in summer-fall months (Figure 4).

\subsection{Ground Water Table (GWT)}

The temporal changes of the GWT depths are given in Figures 5-7. These data clearly indicate the followings: There is a hydraulic gradient in the Hula Valley underground waters from high in the northern part to lower in the south. The amplitude of monthly changes of the GWT depths (Figure 6) is higher in the south and much lower in the northern part of the valley. In other words, there is an underground hydraulic pressure from north towards south. Comparative ANOVA Test $(p<0.05)$ between monthly values of GWT in the north and south clearly confirms it: Northern averaged depth of GWT is $1.36 \mathrm{~m}(\mathrm{SD}=0.22 \mathrm{~m})$ below surface and in the south it is $2.31 \mathrm{~m}(\mathrm{SD}=0.63 \mathrm{~m})$ and the significance level of $\mathrm{p}<0.0001$. Temporal decline of the GWT depth is given in Figure 7 as polynomial regression between the GWT decline and months with significance level of $p<$ 0.0001 and $r^{2}$ of 0.276 (north) and 0.434 (south). 

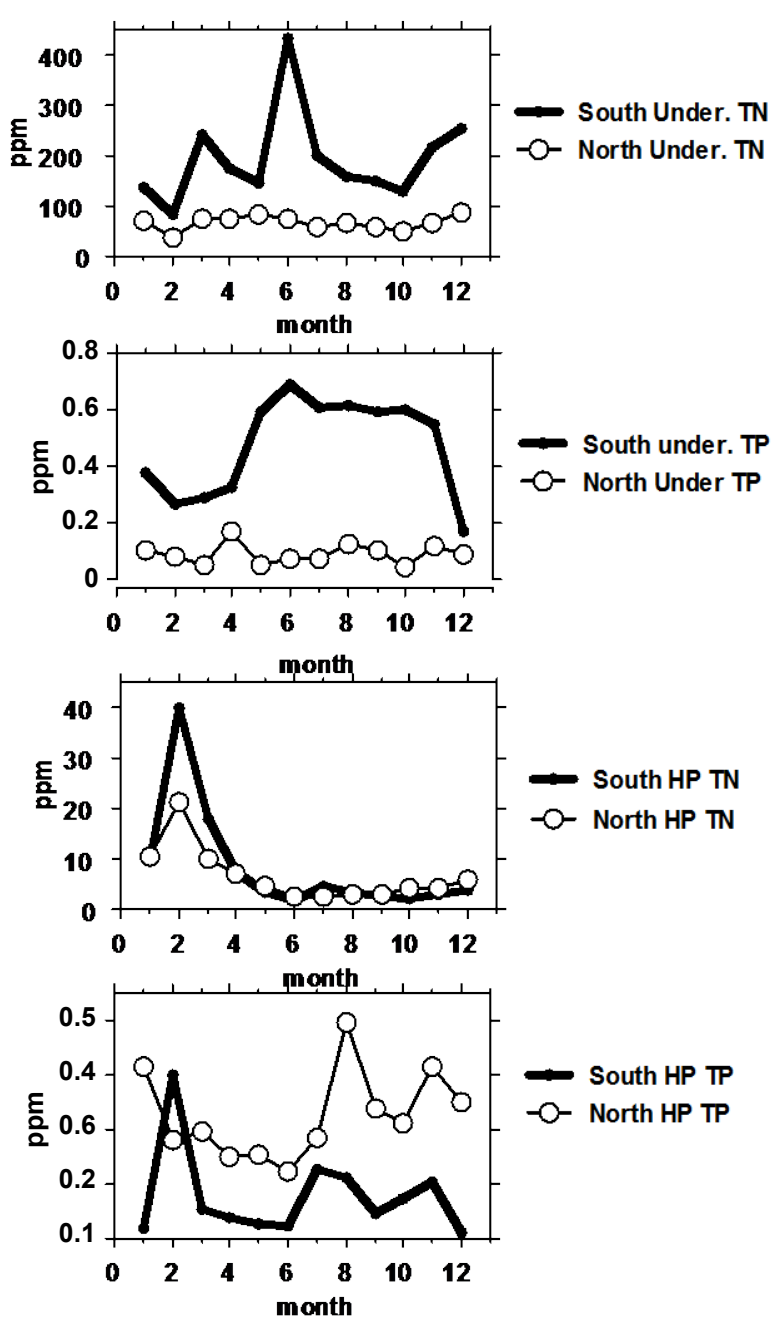

Monthly Averages (1994-2008): North\& South, TN\& TP, HP\&Under

Figure 2. Monthly averages of nutrient (TP, TN) concentrations $(\mathrm{ppm})$ in underground waters (under), running waters (HP), in the Northern and Southern Hula Valley region.

Table 1. Annual averages (SD) of TP and TN concentrations ( \pm SD) of underground (Under) and running (HP) waters in northern $(\mathrm{N})$ and southern $(\mathrm{S})$ drills and stations.

$\begin{array}{cc}\text { HP North TN } & 7(5) \\ \text { HP North TP } & 0.326(0.082) \\ \text { HP South TN } & 8(11) \\ \text { HP South TP } & 0.178(0.080) \\ \text { Under North TN } & 67(14) \\ \text { Under North TP } & 0.091(0.036) \\ \text { Under South TN } & 193(90) \\ \text { Under South TP } & 0.473(0.173)\end{array}$

\subsection{Seasonal Changes}

Temporal analysis of the dynamics of nutrient concentrations was carried out by comparative ANOVA $(\mathrm{p}<$ 
0.05 ) test between winter (January-May, November-December) and summer (June-October) seasons. The results are given in Table 4.

Insignificant differences between summer and winter were indicated when the water chemistry of all 14 drills were analyzed. On the contrary significant differences of water composition (TP \& TN) of the running waters were documented.

\section{Discussion}

The major question to be answered contain two major parts: 1) What is the impact of running waters as well as the flushing (infiltration) flux of water through the section of the shallow soil layers, and 2) Is it possible that subterranean flows resulted by hydraulic gradient sloped north-south has an impact on the chemical composition of the underground waters? The difference between the chemical compositions of the underground waters is prominent when ANOVA Test $(\mathrm{p}<0.05)$ was comparatively done for the southern and northern grouped drills,
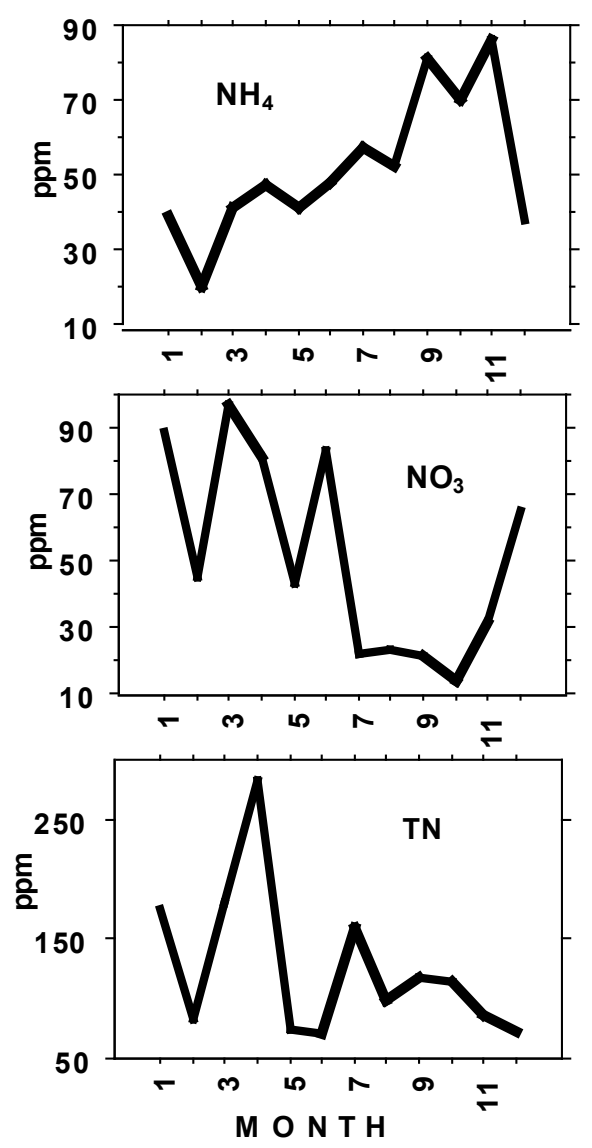

Figure 3. Monthly averages of Nitrogen-nutrients $\left(\mathrm{NH}_{4}, \mathrm{NO}_{3}, \mathrm{TN}\right)$ concentrations (ppm) in the underground waters in the Hula Valley.

Table 2. Annual averages (SD) of $\mathrm{N}$ and $\mathrm{P}$ form concentrations (ppm) in the northern and southern underground waters.

\begin{tabular}{cccccc}
\hline & $\mathbf{N H}_{\mathbf{4}}$ & $\mathbf{N O}_{3}$ & $\mathbf{T D N}$ & $\mathbf{T D P}$ & PO $_{4}$ \\
\hline North & 3.5 & 54.8 & 62.9 & 0.028 & 0.033 \\
North (SD) & 5.9 & 97.25 & 89.3 & 0.021 & 0.026 \\
South & 81.2 & 63.7 & 166.7 & 0.287 & 0.381 \\
South (SD) & 114.3 & 181.6 & 380.1 & 0.497 & 0.567 \\
\hline
\end{tabular}



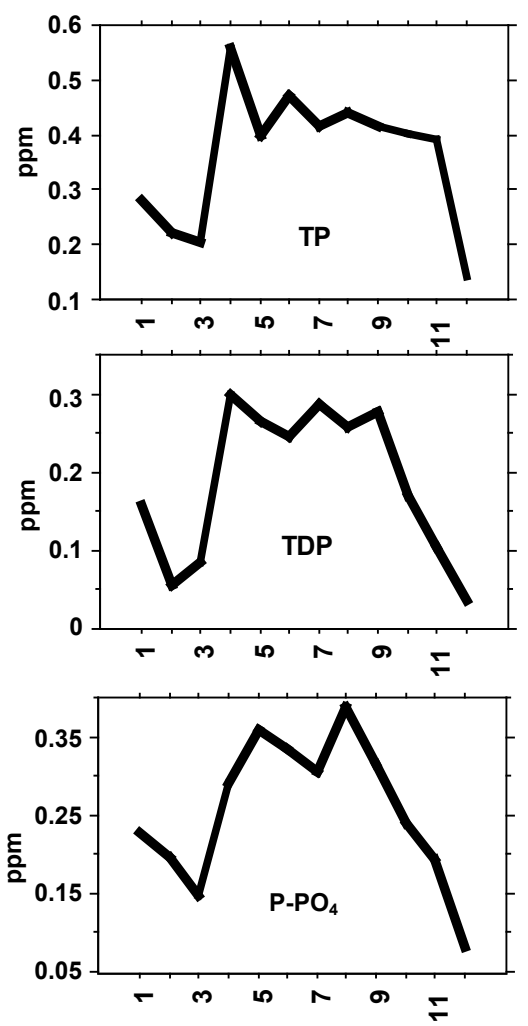

Figure 4. Monthly averages of Phosphorus-nutrients (TP, TDP, $\left.\mathrm{P}-\mathrm{PO}_{4}\right)$ ) concentrations $(\mathrm{ppm})$ in the underground waters in the Hula Valley.
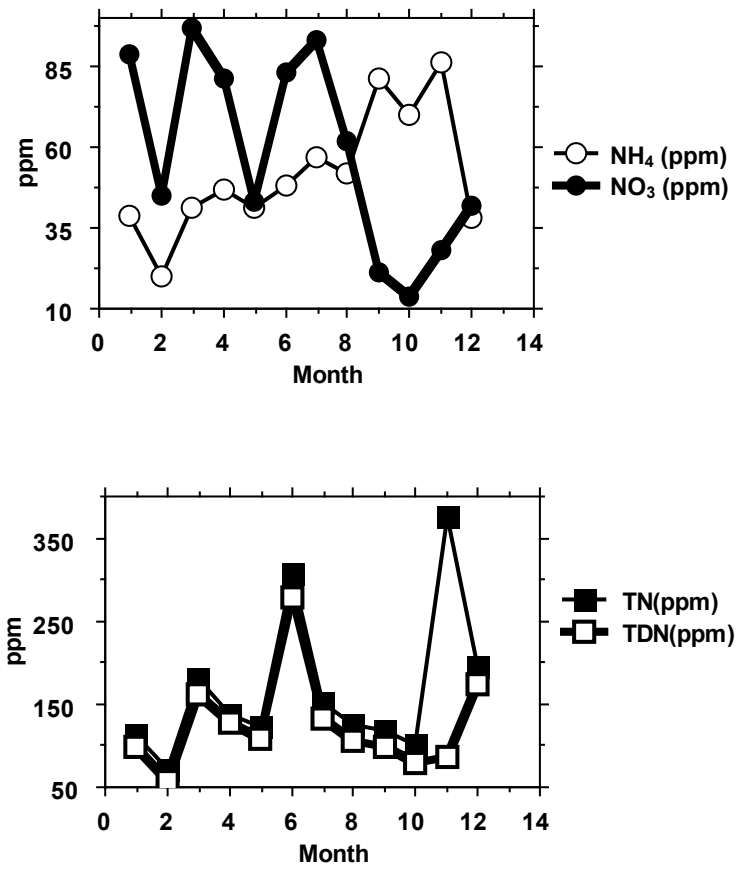

Figure 5. Monthly averages of nutrient $\left(\mathrm{NH}_{4}, \mathrm{NO}_{3}, \mathrm{TN}\right.$, TDN) concentrations (ppm) in the underground waters in the Hula Valley. 


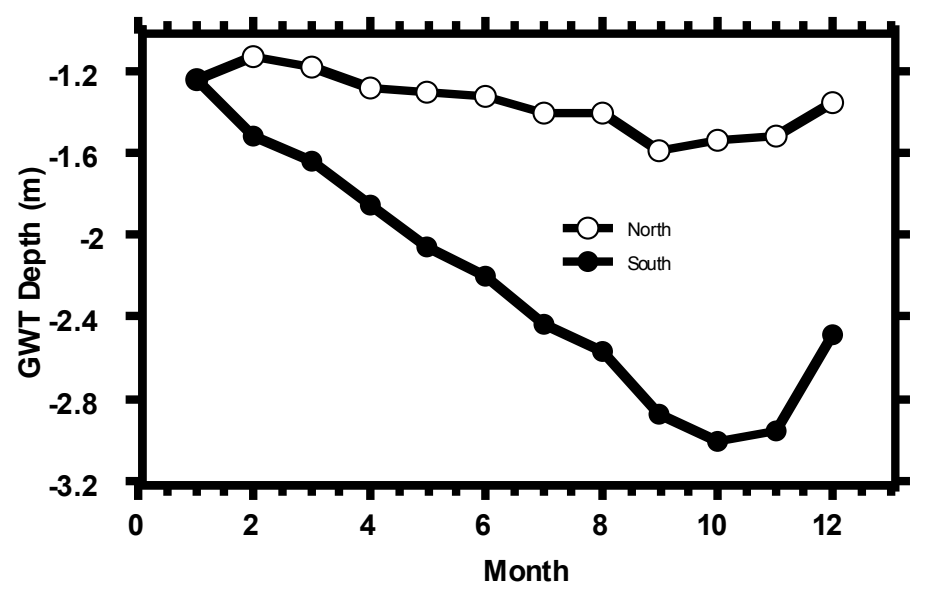

Figure 6. Monthly means (2002-2014) of the depth of Ground Water Table below soil surface, in 14 drills in the Northern and Southern parts of the Hula Valley.
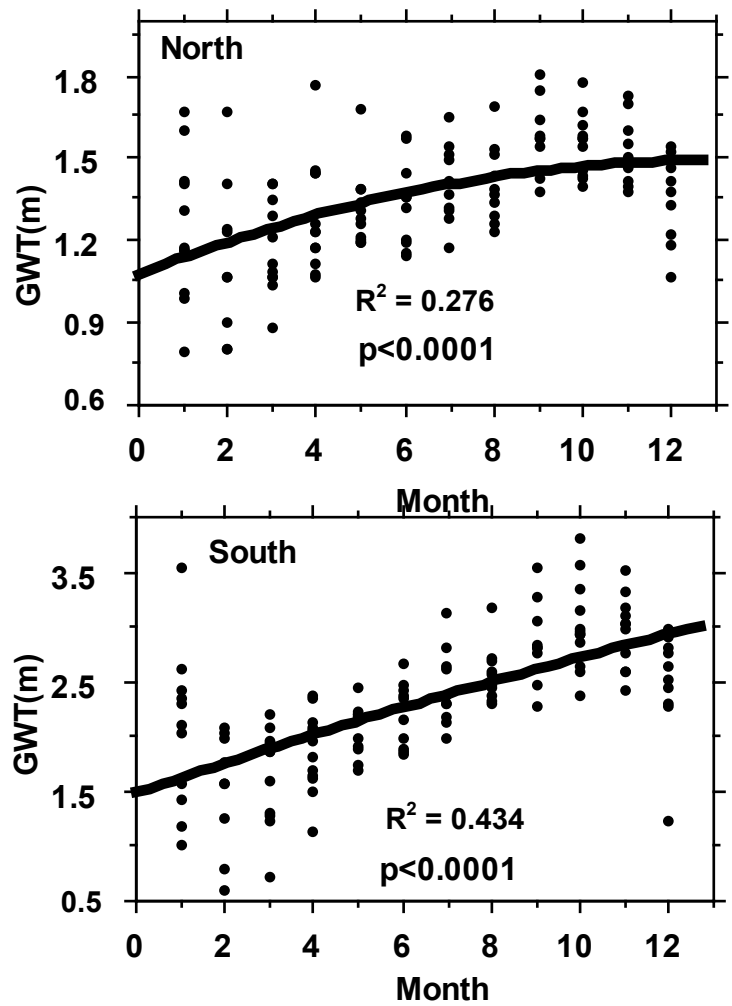

Figure 7. Polynomial regressions between monthly values of Ground Water Table depths and months. Regression parameters are given.

as shown in Table 3 . Results in Table 3 indicate prominent higher concentrations of ammonium, TN, TDN in the south but insignificant difference of Nitrate between north and south. The difference of all Phosphorus forms between North and South was clearly significant with higher levels in the South. These dissimilarities between North and South are the opposite in running waters and undergrounds. Therefore it is suggested that an underground accumulation of nutrients (except nitrates) in the Southern part of the underground is carried out through top-down water mass motion from North to South. The underground water migrations through the preferential water pathways probably enhance two types of processes: 1) an erosion impact resulted in by the significant 
higher Particulate- $-\mathrm{P}$ concentration in the south, and 2) accumulation of dissolved nutrient of ammonium and TDN in the South. Nevertheless, one more critical parameter probably has a significant impact on nutrient accumulation and GWT decline in the southern underground waters is the potential pure water loss due to the higher Evapo-Transpiration in the south resulted by higher land use cover by deep rooted trees (orchards). Evapo-Transpiration might be the dominant impact on both GWT decline and nutrient concentrations enhancement. More than $90 \%$ of $\mathrm{TN}$ is Total Inorganic Nitrogen ( $\mathrm{TIN}=\mathrm{NH}_{4}+\mathrm{NO}_{3} ; \mathrm{NO}_{2}$ is negligible) indicating minor impact of erosion on Nitrogen migration whilst the proportion between Particulate-P and TDP is approximately 1:1. Consequently, erosion and enhancement of TDP are similarly affecting increase of TP concentration. The soil geochemistry indicates a higher level of carbonates (mineral trait) [4]-[6] in the South and higher organic matter in the North. It is likely that deeper level of GWT (see next chapter) together with reductive conditions in the south part of the valley enhance ammonium and TDN increase but no significant change of Nitrate concentrations. The increase of Ortho-P, TDP as well as Particulate-P is due to both reductive conditions and underground erosion effect.

Results presented in Table 4 emphasize the underground contributions of nutrients. Although there are temporal differences of running waters composition the seasonal changes of the underground waters are not significant.

Results shown in Figures 6-9 indicate the followings: the multiannual averaged depth of the underground surface water is $1.36 \mathrm{~m}$ in the North and $2.31 \mathrm{~m}$ in South. ANOVA $(\mathrm{p}<0.05)$ test indicates significant $(\mathrm{p}<$ 0.0001 ) difference between north and south. The underground GWT decline annually from winter (January-February) to summer (September-October) is shown in Figures 6-7. The amplitude of the monthly fluctuations (Figure 8) is large in the South and shorter in the North. These data emphasize the seasonal impact of the underground hydraulic gradient between north and south: lower during rainy season and higher in summer (Figure 9). The averaged GWT depth in south is lower in summer by $44 \mathrm{~cm}$ from the winter mean and in the north it is lower by $17 \mathrm{~cm}$. ANOVA test indicated significant $(\mathrm{p}<0.0001)$ differences between winter and summer averages in both south and north parts of the valley. Polynomial Regression between north and south GWT level decline which is a projection of the hydraulic gradient between north and south underground GWT level is partly linear (Figure 9) with a small leveling off at the deepest range, which is typical to the end

Table 3. Results of ANOVA Test $(\mathrm{p}<0.05)$ comparison between chemical compositions (ppm) (TP, TDP, Particulate-P, $\mathrm{P}_{-} \mathrm{PO}_{4}, \mathrm{TN}, \mathrm{NH}_{4}, \mathrm{NO}_{3}, \mathrm{TDN}$ ) of the southern and northern drills underground waters: averages and significance level (p).

\begin{tabular}{cccc}
\hline Element & North $(\mathbf{p p m})$ & South $(\mathbf{p p m})$ & $\mathbf{p}$ \\
$\mathbf{N H}_{\mathbf{4}}$ & 3.54 & 83.4 & $<0.0001$ \\
$\mathbf{N O}_{3}$ & 54.8 & 63.7 & NS \\
$\mathbf{T D N}$ & 62.9 & 166.7 & 0.0460 \\
$\mathbf{T N}$ & 70.7 & 201.6 & 0.0235 \\
$\mathbf{P - P O}$ & 0.033 & 0.381 & $<0.0001$ \\
$\mathbf{T D P}$ & 0.028 & 0.287 & 0.0001 \\
$\mathbf{T P}$ & 0.092 & 0.528 & $<0.0001$ \\
Particulate-P & 0.064 & 0.241 & 0.0023 \\
\hline
\end{tabular}

Table 4. Nutrient concentration averages (SD) $\left(\mathrm{NH}_{4}, \mathrm{NO}_{3}, \mathrm{P}-\mathrm{PO}_{4}, \mathrm{TDN}, \mathrm{TDP}, \mathrm{TN}, \mathrm{TP}\right)$ in the underground waters (14 drills) during summer (June-Oct.) and winter (Jan.-May, Nov.-Dec.) seasons. All differences between summer and winter of all nutrients were insignificant $(\mathrm{p}>0.05)$.

\begin{tabular}{ccc}
\hline Nutrient & Winter $(\mathbf{p p m})(\mathbf{S D})$ & Summer (ppm) (SD) \\
$\mathbf{N H}_{4}$ & $47.5(100.4)$ & $61.5(97.6)$ \\
$\mathbf{N O}_{3}$ & $93.6(324.4)$ & $54.6(167.8)$ \\
$\mathbf{P - P O}_{4}$ & $0.215(0.433)$ & $0.315(0.544)$ \\
$\mathbf{T D N}$ & $123.0(250.1)$ & $138.6(380.0)$ \\
$\mathbf{T D P}$ & $0.154(0.345)$ & $0.247(0.492)$ \\
$\mathbf{T N}$ & $182.3(433.1)$ & $160.5(419.5)$ \\
$\mathbf{T P}$ & $0.484(1.661)$ & $0.430(0.564)$ \\
\hline
\end{tabular}




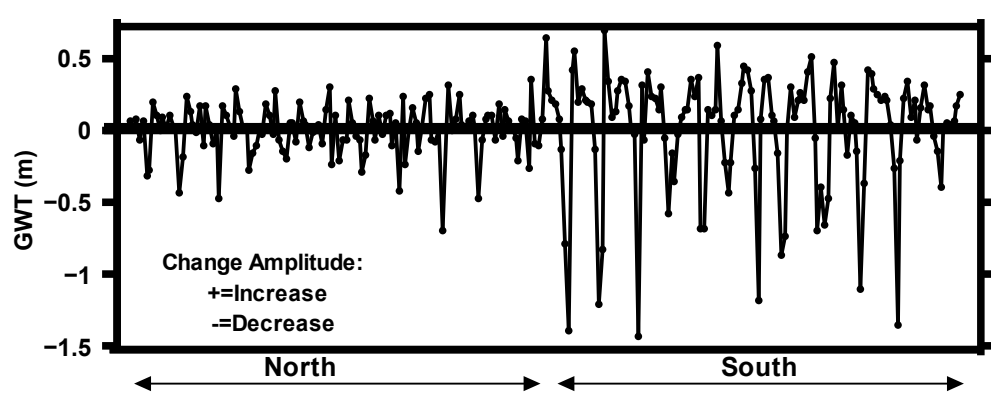

Figure 8. Monthly changes (m) of the amplitude of Ground Water Table Depths in the northern (left side) and southern (right side) of the Hula Valley.

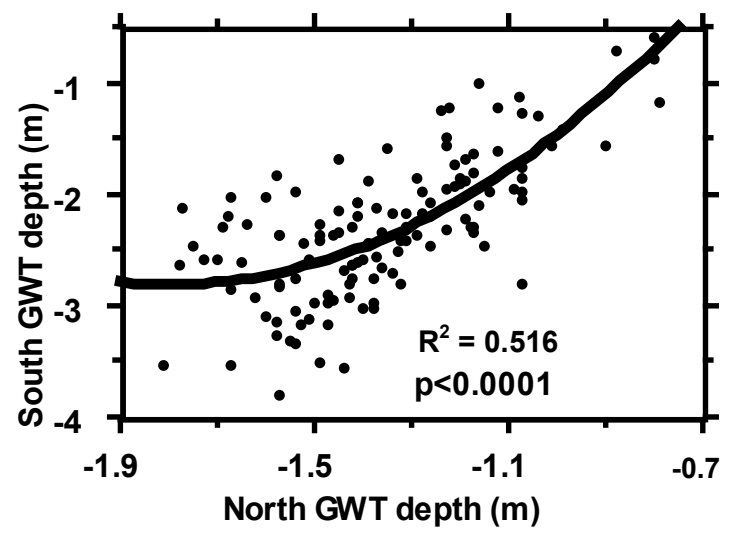

Figure 9. Polynomial Regression between North and South Ground Water Table depths $(\mathrm{m})$ in the Hula Valley (2002-2014).

of the summer-fall period. Then, GWT decline in the north is not simultaneously accompanied by a decline in the south. It is likely that top-down nutrient migration down from soil surface is not much varying over the entire valley and is a dependant of rain regime. Nevertheless, horizontal migration of underground water from the north to south carries (dissolved and suspended) nutrients as an additional support to the southern GWT load from north. These fluxes of water migration loaded with nutrient from north to south exist irrespectively to the plastic barrier implementation as part of the Hula Project by takeover through underneath or aside preferential pathways.

These processes are operated not only because of hydraulic pressure (gradient) but also as a result of the higher capacity of preferential space for water migration in the mineral soil of the southern part of the Valley. The second significant parameter which enhances nutrient concentrations in the southern underground water is Evapo-Transpiration which is also responsible for the deepening of the GWT level.

\section{Summary}

It has been found that there is an underground hydraulic gradient of higher pressure in the northern part and lower pressure in the southern part of the Hula Valley. The outcome is that water and nutrient migration is from north to south. Nutrients and water migrate through the underground preferential pathways. Concentrations of Nitrogen and Phosphorus substances are higher in the north and GWT is lower as a result of intensive ET (Evapo-Transpiration) by the light-calcareous soil and transpiration done by deep rooted trees. Nutrient concentrations in the southern GWT are not unlimited. It is not impossible that it is due to an enigmatic migration of water and nutrients to deeper layers.

\section{Acknowledgements}

This research was funded by: 1) Hula Project, Research Proposal, Jewish National Fund and Water Commission 
to Migal: Gophen, M.-Scientific coordinator and chair person of the Hula Committee; Meron, M., Orlov-Levine, V. and Tsipris, Y. Tsipris-GWT and climatological monitoring; Natanzon, T. and Yasur, E. assistance; Bar-Ilan, Y. and Lab. Team of analytical chemistry; 2) Israeli-Canadian Wetlands Project: International Institute for Sustainable Development (IISD), Winnipeg, Manitoba, Canada, and Israe JNF (Venema, H. and Oborne, B.) to Migal (Gophen, M.).

\section{References}

[1] Dimentman, Ch., Bromley, H.J. and Por., F.D. (1992) Lake Hula Reconstruction of the Fauna and Hydrobiology of Lost Lake. The Israeli Academy of Sciences and Humanities, Jerusalem, 170 p.

[2] Karmon, Y. (1956) The Northern Hula Valley, Its Natural and Cultural Landscape. The Magnet Press, 108 p. (In Hebrew)

[3] Gophen, M. (1994-2006) Hula Project Annual Reports: Chapters: Chemistry and Hydrology. Levin-Orlov, V., Tsipris, Y. and Meron, M., Eds., GWT and Climatological Survey, Jewish National Foundation \& Water Commission. (1994-2005 in Hebrew, 2006 in English)

[4] Gophen, M. (2004) Water Utilization in a Semi-Arid Zone, the Hula Valley (Israel): Pollutant Removal, Agriculture and Ecotourism Management. In: Zreiny, F. and Hotzl, H., Eds., Water in the Middle East and in North Africa: Resources, Protection, and Management, Springer-Verlag, Berlin, 207-226.

[5] Gophen, M. (2006) The Lake Kinneret Drainage Basin: Headwater Discharges, Hydrology and Nutrient Dynamics in the Hula Valley Wetland. In: Krecek, J. and Haigh, M., Eds., Environmental Role of Wetlands in Headwaters, Vol. 63, Springer, Berlin, 233-236.

[6] Payne, R. and Gophen, M. (2012) The Hula Peatland: Past, Present and Future. Mires and Peat, 9, 6 articles. 
Scientific Research Publishing (SCIRP) is one of the largest Open Access journal publishers. It is currently publishing more than 200 open access, online, peer-reviewed journals covering a wide range of academic disciplines. SCIRP serves the worldwide academic communities and contributes to the progress and application of science with its publication.

Other selected journals from SCIRP are listed as below. Submit your manuscript to us via either submit@scirp.org or Online Submission Portal.
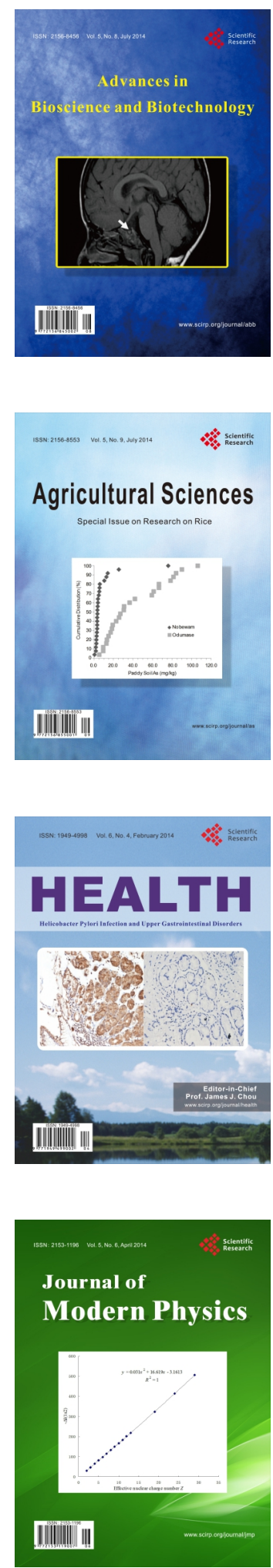
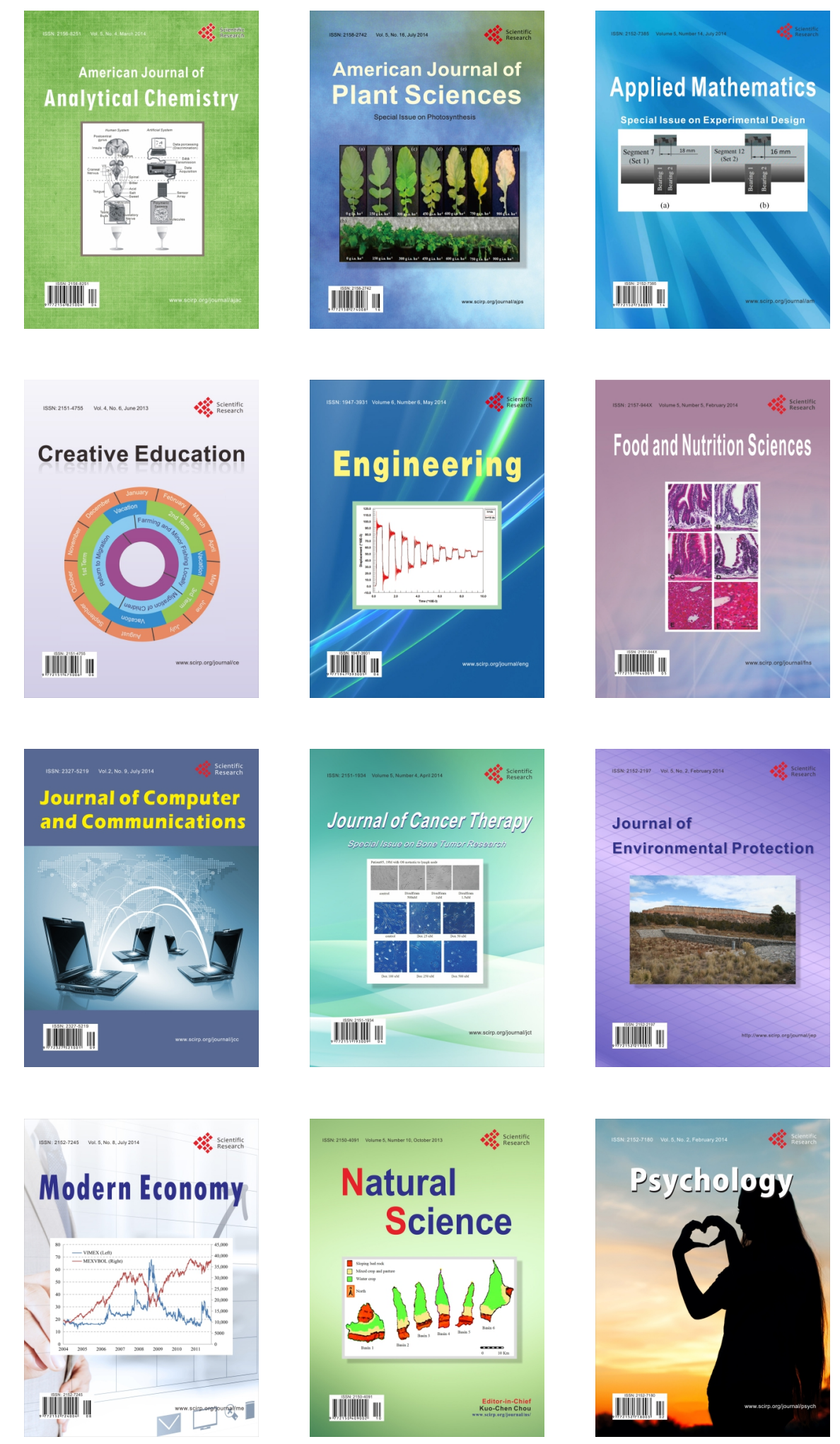